\title{
A Review of Tchaikovsky: A Self-Portrait by Alexandra Orlova ${ }^{1}$
}

$\mathcal{P}$ yotr Chaikovsky repeatedly expressed in his letters a dread that, because of the popularity of his music, people would one day examine his personal life and write biographies. What he could not have foreseen was that books would appear claiming to speak in his name, with the implication that they are his autobiographies. After Tchaikovsky: A Self-Portrait by V. Volkoff (1974) and Piotr Ilyich Tchaikovsky: Letters to His Family; An Autobiography by Galina von Meck (1981), we now get another "self-portrait," this time by the Soviet music historian Aleksandra Orlova. This is a reworked version of a book that was first published in Leningrad in 1976 under a more suitable title, P. I. Chaikovskii o muzyke, o zhizni, o sebe: Literaturnaia kompozitsiia A. A. Orlovoi (P. I. Chaikovsky on music, on his life, on himself: A literary compilation by Aleksandra Orlova).

As Aleksandra Orlova tells us in the preface to the English edition, she established an affinity with this composer when she worked for two years (1938-39) at the Chaikovsky Museum in Klin, housed in what was once his home. She felt so close to him, she writes, that she had the feeling she could at any moment hear his voice or see him enter the room. This privileged affinity apparently gives her the right to regard her collage of excerpts from Chaikovsky's letters, diaries, and articles as the equivalent of his "autobiography" and even as his "confessions," comparable to those of Jean-Jacques Rousseau.

As Chaikovsky's English biographer John Warrack had occasion to observe in his review of this book, published in the Times Literary Supple-

1 Review of Tchaikovsky: A Self-Portrait, by Alexandra Orlova, trans. R. M. Davison with a forward by David Brown (Oxford: Oxford University Press, 1990). Originally published in Slavonic and East European Review 70 (July 1992): 541-44. 
ment under the suggestive title "Poisonous Rumours," Orlova's way of handling Chaikovsky's texts leaves a great deal to be desired. ${ }^{2}$ In a freewheeling paste-and-scissors method, she glues together snippets from the composer's frank and open letters to his younger brothers Anatoly and Modest, from more guarded ones to his friends and colleagues, and from formal letters to various musicians (to say nothing of his published essays on musical topics) and shapes it all into a continuous narrative, supposedly written by Chaikovsky. Another feature of the book is the constant tampering with chronology, with tenses of verbs, and with other aspects of the original texts. The words may be for the most part Chaikovsky's own, but they are shuffled around so that they say what Aleksandra Orlova wants them to say. All this is most unfortunately reminiscent of the rearrangement of quotations developed by Soviet cultural historians in Stalinist and post-Stalinist times to distort the political views of various writers and artists, even though, in this particular case, the agenda is obviously not political.

Aleksandra Orlova is right to chide Soviet censorship for removing all evidence of the composer's homosexuality from his writings published from the 1930s onwards. But it somehow never occurred to her to try to learn more about this subject, and about how it affected Chaikovsky and his contemporaries. In an article she published in the New York Russianlanguage newspaper Novoe russkoe slovo in 1987, Orlova pointed out that she had repeatedly "described how [Chaikovsky] was tormented by this anomaly throughout his life, the anomaly that was a calamity, a curse laid on him by fate." And further in the same article she states that "being a highly decent and honorable man, he regarded his anomaly as a disgrace that could never be effaced."

Now, anyone who has read Chaikovsky's diaries, published by his brother Ippolit, ${ }^{3}$ or his letters to his younger brothers, will know that this does not reflect the composer's feelings. He always maintained that he was not guilty for the way nature made him. If anything tormented him, it was the possibility of invidious gossip that could make his father or sister ashamed of him. This fear led to his ill-advised marriage, followed by a

2 Times Literary Supplement, 9 November 1990.

3 Petr Chaikovskii, Dnevniki [Diaries], 1873-1891 (Moscow and Petrograd: Glavlit, 1923). 
nervous breakdown, after which he made a comfortable adjustment to his sexual orientation. Because Orlova is unable to perceive evidence of homosexuality in Chaikovsky's writings and in memoirs about him, her "self-portrait" says nothing about the formative influence of his classmate, the poet Aleksei Apukhtin, or the happiness he experienced in his homosexual liaisons with his valet-lover Aleksei Sofronov, with Ivan Klimenko (referred to in the composer's letters as "Climena") and with the violinist Iosif Kotek, among others.

A similar lack of information underlies Orlova's view that, in the 1890s, the attitude to homosexuality in Russia was similar to that in the USSR under Stalin and in England in the reign of Queen Victoria. But if one looks at the Russian press at the time of Oscar Wilde's trial in 1895, when the periodicals of the English-speaking world wrote of him with revulsion and fury, one will see that Russian journalists, even such conservative ones as Vasily Rozanov, took the side of Wilde and saw him as a brilliant artist, unfairly persecuted by hypocritical authorities. The most visible homosexual in Russia at the time of Chaikovsky's death was the Grand Duke Sergei Aleksandrovich, brother of Alexander III and uncle of Nicholas II. His love affairs with men were known to everyone in Russia and written about in the press of Western countries. The explorer Nikolai Przhevalsky, Chaikovsky's friend Aleksei Apukhtin and most of the World of Art circle, headed by Sergei Diaghilev, were all quite openly homosexual.

Unaware of any of this, Aleksandra Orlova set about spreading her hypothesis of Chaikovsky's enforced suicide and of a conspiracy to hide it. Shortly after her departure from the Soviet Union in 1979, her articles on this subject began appearing in the West in Russian and in English. Two prominent musicologists, Joel Spiegelman in America and David Brown in England, became Orlova's disciples. ${ }^{4}$ The latter wrote in his entry on Chaikovsky in the authoritative New Grove Dictionary of Music and Musi-

4 Joel Spiegelman (b. 1933) is actually a pianist, harpsichordist, conductor, and composer who divides his time between the United States and Russia. Spiegelman's article for High Fidelity magazine ("The Trial, Condemnation and Death of Tchaikovsky," February 1981, 49-51), in which he uncritically retailed Orlova's contentions as established facts, was more or less the sum total of his musicological output.-Ed. 
cians, reprinted in The New Grove Russian Masters 1, "That [Chaikovsky] committed suicide can hardly be doubted ... That he died of cholera ... cannot be credited." 5

The gist of Aleksandra Orlova's revised version of the composer's death, accepted by David Brown and numerous others, is that shortly before the first performance of his Sixth Symphony, the composer became erotically involved with the nephew of a Count Stenbock-Fermor, who threatened to complain to Tsar Alexander III about this. ${ }^{6}$ A group of Chaikovsky's fellow alumni from the School of Jurisprudence in St. Petersburg heard about this and convoked a "court of honor," which condemned the composer to death for sullying the uniform of their alma mater. $\mathrm{He}$ obediently took poison (arsenic according to the New Grove). Then, a monstrous conspiracy that involved the composer's family, some of the best-known physicians in Russia, and the imperial court covered up the suicide and palmed it off as a cholera infection. How does Aleksandra Orlova know all this? She was told by a man named Aleksandr Voitov in 1966 that he had heard about it as a teenage boy in 1913 from the widow of one of the members of the "court of honor" who heard about it from her husband, who died in 1902.

Actually, Chaikovsky's death is one of the best documented on record. Almost every hour of the last five days of his life is accounted for.

5 David Brown, "Tchaikovsky," in The New Grove Dictionary of Music and Musicians, ed. Stanley Sadie, vol. 18 (London: Macmillan, 1980), 606-36; Brown, "Piotr Il'yich Tchaikovsky," in The New Grove Russian Masters 1: Glinka, Borodin, Balakirev, Musorgsky, Tchaikovsky (London: Macmillan, 1986), 145-250. Citations are from Russian Masters, 223-24.

6 Actually (and quite ironically), it was Aleksandr Poznansky, the author of the book SK recommends at the end of this review, who introduced this now famous nephew into the story in his first, and very effective, rebuttal of Orlova's account. In recounting the version of the rumor that she had heard, Orlova had only stated that it was a certain Count Stenbock-Fermor who had brought the charges against Chaikovsky. Poznansky, diligently researching the possibilities thus raised, determined, on the basis of the Genealogisches Handbuch der baltischen Ritterschaften (Golitz, 1930), that "the only young man who might answer Orlova's description would have been Aleksandr Stenbock-Fermor, the son of Count Vladimir Stenbock-Fermor" (see Poznansky's “Tchaikovsky's Suicide: Myth and Reality," 19th-Century Music 11, no. 3 [Spring 1988]: 203). As soon as Poznansky came up with his name, this Aleksandr was ensconced as the official victim in Orlova's subsequent retellings and those of her followers, to Poznansky's considerable amusement.-Ed. 
There is no known poison that can mimic cholera symptoms and cause a person to die slowly over a period of four days. Why did those fellow students of long ago pick on Chaikovsky, who kept his sex life private, and why did they not condemn to death other School of Jurisprudence alumni, such as Apukhtin or Prince Vladimir Meshchersky, who flaunted their sexual orientation, were involved in major homosexual scandals, and yet escaped with impunity? Shortly after Orlova's revelations, Ivan Stenbock-Fermor of Palo Alto, California, informed me that he had the family tree of the various branches of his family and that both the Count Stenbock-Fermor, who was a friend of Alexander III and went hunting with him, and the count's wife were their parents' only children, so that there could not have been a nephew to be involved with Chaikovsky.

The claims of Aleksandra Orlova and her followers were eagerly accepted in the West. As the music critic of the New York Times Donal Henahan wrote, ${ }^{7}$ he wanted to believe it because it reminded him of a nineteenth-century Russian novel. (What novel could he possibly have had in mind? Or did he confuse Russian novels with Italian opera?) But from 1981 on, Orlova's version was repeatedly challenged in print by critics and historians. Alan M. Kriegsman, the dance critic of the Washington Post, described her evidence as "a tissue of inferences from one unsupported conjecture to another" and wrote that "by the same logic we could also decree that Tchaikovsky ... was the real author of Wagner's Ring of the Nibelung." 7 The hypothesis was thoroughly debunked by the historian Aleksandr Poznansky in his essay "Tchaikovsky's Suicide: Myth and Reality" in 19th-Century Music, ${ }^{9}$ a part of his subsequently published book.

To Aleksandra Orlova's collection of third-hand rumors, never traceable to anyone who knew Chaikovsky, Poznansky opposed a large number of statements, letters, diaries, and memoirs by the composer's relatives, friends, and doctors who were with him at the time of his death. He also offered a profusion of new information about such matters as the cholera

7 Donal Henahan, "Did Tchaikovsky Really Commit Suicide?," New York Times, 26 July 1981.

8 Alan M. Kriegsman, “The Great Suicide Debate,” Washington Post, 28 March 1982.

9 Poznansky, “Tchaikovsky's Suicide,” 199-220. 
control regulations that were in force at the time, the unfortunate series of circumstances that delayed the diagnosis of Chaikovsky's illness, and the attitudes to homosexuality in the 1890s at the School of Jurisprudence and the court of Alexander III. Orlova is clearly aware that her critics have proven her wrong on almost every count, because the depiction of the composer's death that we find in Tchaikovsky: A Self-Portrait differs in most particulars from the versions offered in her earlier articles on this topic. But she still insists on rejecting all factual evidence surviving from the period and cites some new "testimony," consisting, as usual, of unverifiable rumors.

Aleksandra Orlova's book does contain many interesting statements by Chaikovsky on his life, music, and friends, as well as other composers, not otherwise available in English. But because this material is often chronologically skewed and because Orlova does not know the actual nature of Chaikovsky's relationships with his various friends and lovers, the book would be most profitably read after Aleksandr Poznansky's factually informed and genuinely new and revealing recent book, Tchaikovsky: The Quest for the Inner Man. ${ }^{10}$

Prior to writing this piece and its companions in this volume, and long before Aleksandr Poznansky embarked on his ultimately dispositive refutation of the suicide rumor, SK had participated, along with Malcolm Hamrick Brown and Nina Berberova, in the first detailed public challenge to it. This took the form of a letter to the editor of High Fidelity magazine, ${ }^{11}$ which had published Joel Spiegelman's sensationalistic Orlova paraphrase. ${ }^{12}$ The letter shows that Poznansky's efforts, impressive and valuable as they were, were after all unnecessary to undermine the veracity of the hardy fable. The trio of reputable Slavists pointed out that no one who actually knew Chaikovsky (including

10 Alexander Poznansky, Tchaikovsky: The Quest for the Inner Man (New York: Schirmer, 1991).

11 Nina Berberova, Malcolm Brown, and Simon Karlinsky, “Tchaikovsky's 'Suicide' Reconsidered: A Rebuttal," letter to the editor, High Fidelity, August 1981, 49 and 85.

12 See n. 4. 
the composers Glazunov and Rachmaninoff, Chaikovsky's brother Anatoly, or the art connoisseur Vladimir Argutinsky-Dolgorukov, who was actually on the scene when Chaikovsky was taken ill at his brother Modest's apartment in St. Petersburg - all of whom Berberova had interviewed in the course of researching her novelized biography, Chaikovskii: Istoriia odinokoi zhizni, published in 1936) had ever doubted that he died of complications from cholera, whereas proponents of the suicide rumor were invariably people without direct access to him. They assessed the role of contemporary attitudes toward homosexuality as an incubator of scandalous rumors during the composer's lifetime. They showed that public health standards in Russia (revised and widely published the year before Chaikovsky's death) were consistent with the way in which the composer's body was treated at his funeral. They used contemporary documents, including Tolstoi's last novel, Resurrection, to show that public attitudes toward homosexuality had become more tolerant by the 1890 s, rendering the possibility of a mortal threat of exposure implausible. They had a bit of fun detailing the escapades of homosexuals prominent in Russian public affairs in the late nineteenth century, including members of Tsar Alexander III's court (and even the tsar's own brother). They showed that Russian journalists, unlike those in the English-speaking countries or in Germany, treated Oscar Wilde sympathetically at the time of his trial for "gross indecency," which took place two years after Chaikovsky's death. "So," they concluded,

even though Tchaikovsky indeed feared the exposure of his homosexuality for much of his life, he had less cause to fear the consequences in the early 1890s than before. Furthermore, at the end of his life, he associated with Sergei Diaghilev and other younger homosexuals who later were to form the World of Art group. Unlike the generation to which Tchaikovsky belonged, these younger men felt no qualms about their homosexuality. Had any of them been aware of his being forced into suicide due to the sexual orientation they all shared, surely someone in the World of Art group would have taken advantage of the relaxation of censorship after the 1905 revolution to draw public attention to such an outrage inflicted on the composer they all venerated.

Alas, to no avail. The racy rumor continued to spread on the strength of its sheer value as titillation, and the chief music critic for the New York 
Times, Donal Henahan, did his best to abet it, deriding the High Fidelity letter as "scattershot and undocumented[!]," and declaring himself ready (indeed, "yearning") to believe Orlova's version because it "reeks so heavily of the conspiratorial atmosphere of old Russian novels."13 "We have no idea what novels he means," wrote Berberova, Brown, and SK in weary rejoinder, "but we do know that a music critic should not confuse history with fiction."14

13 Henahan, "Did Tchaikovsky Really Commit Suicide?"

14 Nina Berberova, Malcolm H. Brown, and Simon Karlinsky, "Doubts about Tchaikovsky," letter to the editor, New York Times, 9 August 1981. 